$13^{\text {th }}$ International Conference on

\title{
Dynamic Behavior of a Hydraulic Motor Controlled by a Poppet Type Directional Control Valve
}

\author{
A.M.F. Sallam ${ }^{*}$, A.I. Abdel-Aziz ${ }^{* *}$, M. Galal Rabie ${ }^{* * *}$, M.S. Dwidar ${ }^{\dagger}$
}

\begin{abstract}
This paper is dedicated to investigate the static and dynamic behavior of a hydraulic motor controlled by a hydraulic circuit incorporating a poppet-type directional control valve (DCV) and a pressure reducer. The system is fed by the hydraulic power from a constant pressure source. The pressure reducer is active in one direction of motor rotation. In the other direction, it is by-passed. The studied system and its basic elements were described mathematically and simulated by developing Matlab-Simulink programs, mainly the DCV, pressure reducer, the check valve and the hydraulic motor. The transient response of the system was investigated experimentally and the experimental results were used to validate the simulation program.
\end{abstract}

\section{Nomenclature}

$\mathrm{d}_{\mathrm{L}}=$ Check valve poppet diameter, $\mathrm{m}^{2}$

$\mathrm{d}_{\mathrm{t}}=$ Check valve throttling diameter, $\mathrm{m}$

$\mathrm{f}=$ Damping coefficient, $\mathrm{Nms} / \mathrm{rad}$.

$F_{a}=$ Solenoid (a) force applied on core(a), $N$

$\mathrm{F}_{\mathrm{b}}=$ Solenoid (b) force applied on core (b), N

$\mathrm{F}_{\mathrm{ca}}=$ Core-poppet contact force at section (a), $\mathrm{N}$

$\mathrm{F}_{\mathrm{cb}}=$ Core-poppet contact force at section (b), N

$\mathrm{f}_{\mathrm{cv}}=$ Check valve seats damping coefficient

$\mathrm{f}_{\mathrm{r}}=$ Damping coefficient, Ns/m

$\mathrm{f}_{\mathrm{rc}}=$ Case seat friction coefficient of DCV, Ns $/ \mathrm{m}$

$\mathrm{f}_{\mathrm{rcp}}=$ Friction coefficient of cores (a)\&(b), Ns/m

$\mathrm{F}_{\mathrm{rf}}=$ Poppet-piston contact force, $\mathrm{N}$

$\mathrm{f}_{\mathrm{rp}}=$ Poppet-piston contact damping coef., Ns/m

$\mathrm{f}_{\mathrm{rst} 5} \& \mathrm{f}_{\mathrm{rst} 6}=$ Seat damping coefficient, $\mathrm{Ns} / \mathrm{m}$

$\mathrm{F}_{\mathrm{s} 1}, \mathrm{~F}_{\mathrm{s} 2}, \mathrm{~F}_{\mathrm{s} 3} \& \mathrm{~F}_{\mathrm{s} 4}=\mathrm{DCV}$ seat reaction forces, $\mathrm{N}$

$\mathrm{F}_{\mathrm{s} 5} \& \mathrm{~F}_{\mathrm{s} 6}=\mathrm{PRV}$ seat reaction forces, $\mathrm{N}$

$\mathrm{F}_{\mathrm{s} 7} \& \mathrm{~F}_{\mathrm{s} 8}=$ Check valve seat reaction forces, $\mathrm{N}$

$\mathrm{F}_{\mathrm{sc}}=\mathrm{DCV}$ core (a) seat reaction, $\mathrm{N}$

$\mathrm{F}_{\text {sd }}=\mathrm{DCV}$ core (b) seat reaction, $\mathrm{N}$

$\mathrm{i}=$ Motor number of cylinders

$\mathrm{J}=$ Moment of inertia of rotary parts, $\mathrm{kg} \mathrm{\textrm {m } ^ { 2 }}$ $\mathrm{k}_{1}=$ DCV core (a) spring stiffness, $\mathrm{N} / \mathrm{m}$

$\mathrm{k}_{2}=\mathrm{DCV}$ core (b) spring stiffness, $\mathrm{N} / \mathrm{m}$

$\mathrm{k}_{\mathrm{c}}=\mathrm{DCV}$ core (a) seat stiffness, N/m

$\mathrm{k}_{\mathrm{ca}}=$ DCV poppet (a) seat (1) stiffness, $\mathrm{N} / \mathrm{m}$

$\mathrm{k}_{\mathrm{cb}}=\mathrm{DCV}$ core (b) stiffness, N/m

$\mathrm{k}_{\mathrm{cp}}=$ Core (a) stiffness of DCV, N/m

$\mathrm{k}_{\mathrm{p}}=$ Poppet-piston contact stiffness, $\mathrm{N} / \mathrm{m}$

$\mathrm{k}_{\mathrm{pa}}=$ Poppet seat contact stiffness, $\mathrm{N} / \mathrm{m}$

$\mathrm{k}_{\mathrm{pb}}=\mathrm{DCV}$ poppet (b) stiffness, $\mathrm{N} / \mathrm{m}$

$\mathrm{k}_{\mathrm{s} 1}=$ Poppet (a) spring stiffness of DCV, N/m

$\mathrm{k}_{\mathrm{s} 2}=$ Poppet (b) spring stiffness of DCV, N/m

$\mathrm{k}_{\mathrm{s} 3}=$ PRV poppet spring stiffness, $\mathrm{N} / \mathrm{m}$

$\mathrm{k}_{\mathrm{s} 4}=\mathrm{PRV}$ piston spring stiffness, $\mathrm{N} / \mathrm{m}$

$\mathrm{k}_{\mathrm{s} 5}=$ Check valve spring stiffness, $\mathrm{N} / \mathrm{m}$

$\mathrm{k}_{\mathrm{st5}}=$ PRV stiffness of seat reaction $\mathrm{F}_{\mathrm{s} 5}, \mathrm{~N} / \mathrm{m}$

$\mathrm{k}_{\mathrm{st} 6}=$ PRV stiffness of seat reaction $\mathrm{F}_{\mathrm{s} 6}, \mathrm{~N} / \mathrm{m}$

$\mathrm{k}_{\mathrm{st} 7}=$ Check valve right seat stiffness, $\mathrm{N} / \mathrm{m}$

$\mathrm{k}_{\mathrm{st} 8}=$ Check valve left seat stiffness, $\mathrm{N} / \mathrm{m}$

$\mathrm{L}=$ Length of piston head of PRV, $\mathrm{m}$

$\mathrm{L}_{\mathrm{C}}=$ Motor length of cylinder, $\mathrm{m}$

\footnotetext{
* Egyptian Armed Forces

** Dr Eng. Faculty of Engineering, Ain Shams University

*** Professor of Mechanical Engineering. Modern Academy for Engineering and Technology

$\dagger$ Professor of Mechanical Engineering. Faculty of Engineering, Ain Shams University
} 
$\mathrm{m}_{1}=\mathrm{DCV}$ core mass, $\mathrm{kg}$

$\mathrm{m}_{2}=$ DCV poppet mass, $\mathrm{kg}$

$\mathrm{m}_{3}=$ PRV poppet mass, $\mathrm{kg}$

$\mathrm{m}_{4}=\mathrm{PRV}$ piston mass, $\mathrm{kg}$

$\mathrm{m}_{5}=$ Check valve poppet mass, $\mathrm{kg}$

$\mathrm{P}_{\mathrm{A}}=$ Pressure at port A of DCV, Pa

$\mathrm{P}_{\mathrm{B}}=$ Pressure at port $\mathrm{B}$ of $\mathrm{DCV}, \mathrm{Pa}$

$\mathrm{P}_{\mathrm{c}}=$ Check valve output pressure, $\mathrm{Pa}$

$\mathrm{P}_{\mathrm{ci}}=$ Motor pressure at one defined cylinder, $\mathrm{Pa}$

$\mathrm{P}_{\mathrm{cr}}=$ Check valve cracking pressure, $\mathrm{Pa}$

$\mathrm{P}_{\mathrm{mA}}=$ Check valve input pressure, $\mathrm{Pa}$

$\mathrm{P}_{\mathrm{r}}=$ Output reduced pressure from $\mathrm{PRV}, \mathrm{Pa}$

$\mathrm{P}_{\mathrm{S}}=$ System pressure, $\mathrm{Pa}$

$\mathrm{P}_{\mathrm{T}}=$ Tank (return) pressure, $\mathrm{Pa}$

$\mathrm{Q}_{1}, \mathrm{Q}_{2}, \mathrm{Q}_{\mathrm{L}} \& \mathrm{Q}_{\mathrm{E}}=\mathrm{PRV}$ Flow rates, $\mathrm{m}^{3} / \mathrm{s}$

$\mathrm{Q}_{3}=$ Flow rate through restriction area, $\mathrm{m}^{3} / \mathrm{s}$

$\mathrm{Q}_{\mathrm{A}}=$ Flow rate through port A of DCV, $\mathrm{m}^{3} / \mathrm{s}$

$\mathrm{Q}_{\mathrm{b}}, \mathrm{Q}_{\mathrm{c}}, \mathrm{Q}_{\mathrm{f}} \& \mathrm{Q}_{\mathrm{g}}=$ DCV Flow rates, $\mathrm{m}^{3} / \mathrm{s}$

$\mathrm{Q}_{\mathrm{B}}=$ Flow rate through port $\mathrm{B}$ of $\mathrm{DCV}, \mathrm{m}^{3} / \mathrm{s}$

$\mathrm{Q}_{\mathrm{cv}}=$ Flow rate through check valve, $\mathrm{m}^{3} / \mathrm{s}$

$\mathrm{Q}_{\mathrm{dr}}=$ Total motor drain flow rate from all motor

cylinders, $\mathrm{m}^{3} / \mathrm{s}$

$\mathrm{Q}_{\text {dri }}=$ Motor cylinder drain flow rate, $\mathrm{m}^{3} / \mathrm{s}$

$\mathrm{Q}_{\text {in }}=$ Total motor intake flow rate, $\mathrm{m}^{3} / \mathrm{s}$

$\mathrm{Q}_{\text {ini }}=$ Motor cylinder intake flow rate, $\mathrm{m}^{3} / \mathrm{s}$

$\mathrm{Q}_{\mathrm{m} 1}=$ Flow rate through port 1 of motor, $\mathrm{m}^{3} / \mathrm{s}$

$\mathrm{Q}_{\mathrm{m} 2}=$ Flow rate through port 2 of motor, $\mathrm{m}^{3} / \mathrm{s}$

$\mathrm{Q}_{\mathrm{r}}=$ Outlet flow rate from the $\mathrm{PRV}, \mathrm{m}^{3} / \mathrm{s}$

$\mathrm{Q}_{\mathrm{rd}}=$ Inlet flow rate to the $\mathrm{PRV}, \mathrm{m}^{3} / \mathrm{s}$

$\mathrm{R}=$ Constant area value adjusted on the exit port of

PRV by a manually adjusted restrictor, $\mathrm{m}^{2}$

$\mathrm{R}_{\mathrm{L}}=$ Resistance to internal leakage, $\mathrm{Ns} / \mathrm{m}^{5}$

$\mathrm{R}_{\mathrm{L}}=$ Resistance to leakage, $\mathrm{Ns} / \mathrm{m}^{5}$
$\mathrm{S}_{1}=$ Gap between core\&poppet of DCV, $\mathrm{m}$

$\mathrm{S}_{2}=$ DCV poppets stroke, $\mathrm{m}$

$\mathrm{T}_{\mathrm{L}}=$ Motor loading torque, $\mathrm{Nm}$

$\mathrm{T}_{\mathrm{m}}=$ Total output torque of motor, $\mathrm{Nm}$

$\mathrm{T}_{\mathrm{mi}}=$ Torque due to single motor piston, $\mathrm{Nm}$

$\mathrm{V}_{12}, \mathrm{~V}_{23}=$ Volume of lines connecting DCV, PRV \& check valve, $\mathrm{m}^{3}$

$\mathrm{V}_{3} \& \mathrm{~V}_{4}=$ Volumes of DCV chambers, $\mathrm{m}^{3}$

$\mathrm{V}_{31}=$ Volume of line connecting motor with DCV, $\mathrm{m}^{3}$

$\mathrm{V}_{\mathrm{c}}=\mathrm{PRV}$ chamber $\mathrm{C}$ volume, $\mathrm{m}^{3}$

$\mathrm{V}_{\mathrm{ci}}=$ Motor cylinder volume, $\mathrm{m}^{3}$

$\mathrm{x}_{1 \mathrm{o}}=\mathrm{DCV}$ core (a) spring pre-compression, $\mathrm{m}$

$\mathrm{x}_{2 \mathrm{o}}=\mathrm{DCV}$ poppet (a) spring pre-compression, $\mathrm{m}$

$\mathrm{x}_{\mathrm{a} 1} \& \mathrm{x}_{\mathrm{b} 1}=\mathrm{DCV}$ cores displacements, $\mathrm{m}$

$\mathrm{x}_{\mathrm{a} 1 \mathrm{i}}=\mathrm{DCV}$ core (a) pre-compression, $\mathrm{m}$

$\mathrm{x}_{\mathrm{a} 2} \& \mathrm{x}_{\mathrm{b} 2}=$ DCV poppets displacements, $\mathrm{m}$

$\mathrm{x}_{\mathrm{a} 2 \mathrm{i}}=\mathrm{DCV}$ poppet (a) pre-compression, $\mathrm{m}$

$\mathrm{x}_{\mathrm{b} 1 \mathrm{i}}=\mathrm{DCV}$ core $(\mathrm{b})$ pre-compression, $\mathrm{m}$

$\mathrm{x}_{\mathrm{b} 2 \mathrm{i}}=\mathrm{DCV}$ poppet (b) pre-compression, $\mathrm{m}$

$\mathrm{x}_{\mathrm{c} 1} \& \mathrm{x}_{\mathrm{c} 2}=$ Poppet \& piston displacements, $\mathrm{m}$

$\mathrm{x}_{\mathrm{c} 2 \mathrm{o}}=\mathrm{PRV}$ piston spring pre-compression, $\mathrm{m}$

$\mathrm{x}_{\mathrm{co}}=\mathrm{PRV}$ poppet spring pre-compression, $\mathrm{m}$

$\mathrm{x}_{\mathrm{i}}=$ Motor piston displacement, $\mathrm{m}$

$\mathrm{x}_{\mathrm{n}}=$ PRV inlet poppet valve stroke, $\mathrm{m}$

$\mathrm{z}_{\mathrm{o}}=$ Check valve spring pre-compression, $\mathrm{m}$

$\mu=$ Dynamic viscosity, Pa s

$\alpha=$ Motor bent axis angle, degrees

$\beta=$ Poppet conical-seat angle, $\mathrm{rad}$

$\theta_{\mathrm{mi}}=$ Motor piston rotational angle, degrees

$\rho=$ Oil density, $\mathrm{kg} / \mathrm{m}^{3}$

$\varphi=$ PRV inlet valve poppet angle, $\mathrm{rad}$

$=$ PRV drain valve poppet angle, $\mathrm{rad}$

\section{System Description}

The hydraulic circuit of the investigated system is illustrated by Fig. 1. The hydraulic generator is of constant pressure. It consists of a pressure compensated variable displacement pump, a hydraulic accumulator and a relief valve. The hydraulic generator insures, practically, constant supply pressure $\mathrm{P}_{\mathrm{s}}$. In one direction of rotation, fluid flow to the motor (3) through a pressure reducer (2). In this case, the maximum motor torque is limited by the reduced pressure. In the opposite direction, the pressure reducer is by-passed by the check valve (4) and the motor torque can increase to a maximum value, corresponding to the main relief valve setting.

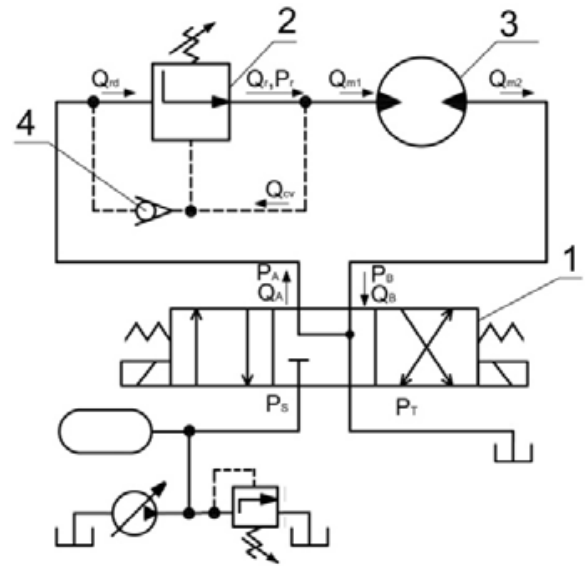

Fig.1 Hydraulic system scheme.

The directional control valve (1) is a 4/3 valve of direct operated poppet type. In its neutral position it connects both of the motor lines to the return line, allowing for free motor motion. Therefore, the position of the door, driven by the motor is locked mechanically. 


\section{Directional Control Valve}

Figure 2 shows a schematic of the studied DCV. It consists of two identical sections ( $a$ and $b$ ). Each of them consists of a solenoid (1) with core (2), spring (3 and 5) and poppet (4) that connects and disconnects different ports to each other. Both solenoids (1 and 6) are normally de-energized. When operated, only one solenoid is energized at a time.

With both solenoids de-energized, poppets ( 4 and 9 ) are set by springs ( 5 and 10) to the right extreme position to block the port $\left(\mathrm{P}_{\mathrm{s}}\right)$, and connect ports $(\mathrm{A}$ and $\mathrm{B})$ with the return port $(\mathrm{T})$. When solenoid (1) is energized, the poppet shifts to the extreme left position. It disconnects the port (A) from the return lint $(\mathrm{T})$ and connects it to the high pressure line (P). The port (B) stays connected to $(\mathrm{T})$. Moreover, by energizing solenoid (6), port $(\mathrm{P})$ is connected to $(\mathrm{B})$ and (A) is connected to $(\mathrm{T})$. The dynamic behavior of the DCV is described by the following equations.

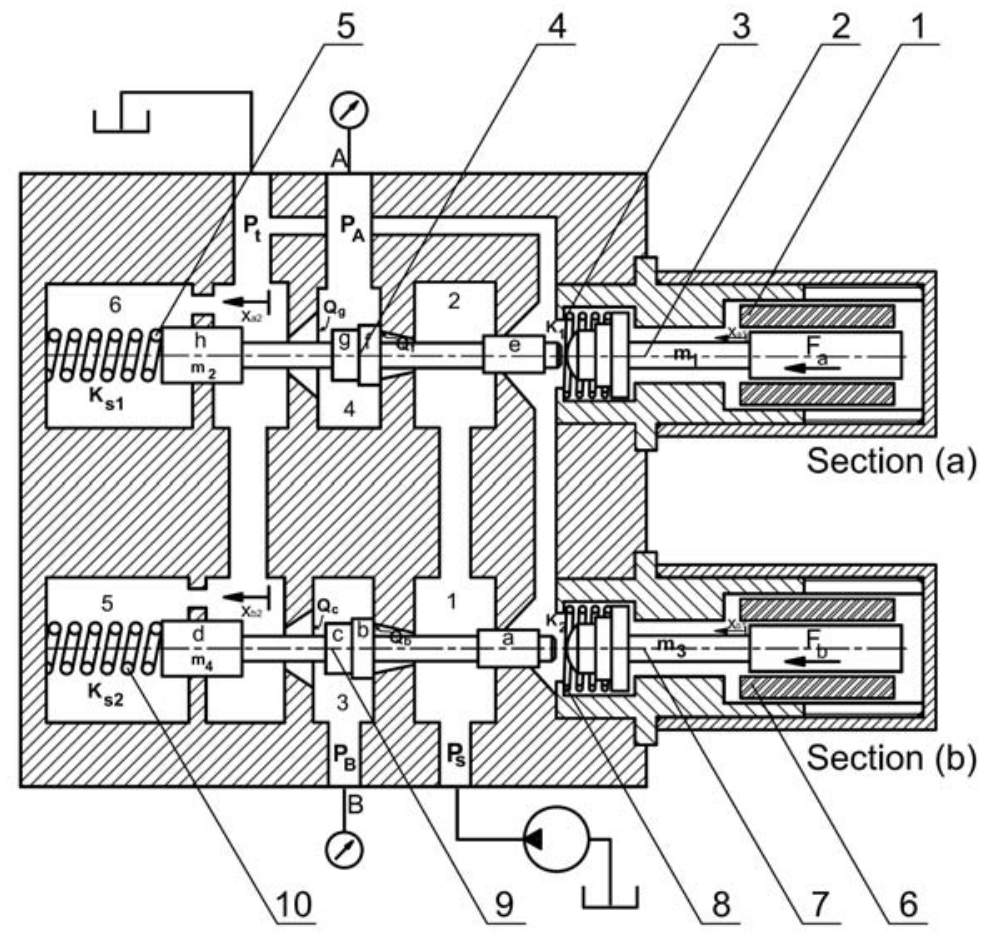

Fig. 2 Schematic of the directional control valve

The flow rates through the valve throttling areas are:

$$
\begin{aligned}
& \mathrm{Q}_{\mathrm{f}}=\mathrm{C}_{\mathrm{d}} \mathrm{A}_{\mathrm{f}}\left(\mathrm{x}_{\mathrm{a} 2}\right) \sqrt{2\left(\mathrm{P}_{\mathrm{S}}-\mathrm{P}_{\mathrm{A}}\right) / \rho} \\
& \mathrm{Q}_{\mathrm{g}}=\mathrm{C}_{\mathrm{d}} \mathrm{A}_{\mathrm{g}}\left(\mathrm{x}_{\mathrm{a} 2}\right) \sqrt{2\left(\mathrm{P}_{\mathrm{A}}-\mathrm{P}_{\mathrm{T}}\right) / \rho} \\
& \mathrm{Q}_{\mathrm{b}}=\mathrm{C}_{\mathrm{d}} \mathrm{A}_{\mathrm{b}}\left(\mathrm{x}_{\mathrm{b} 2}\right) \sqrt{2\left(\mathrm{P}_{\mathrm{S}}-\mathrm{P}_{\mathrm{B}}\right) / \rho} \\
& \mathrm{Q}_{\mathrm{c}}=\mathrm{C}_{\mathrm{d}} \mathrm{A}_{\mathrm{c}}\left(\mathrm{x}_{\mathrm{b} 2}\right) \sqrt{2\left(\mathrm{P}_{\mathrm{B}}-\mathrm{P}_{\mathrm{T}}\right) / \rho}
\end{aligned}
$$

Throttling areas $\mathrm{A}_{\mathrm{f}}, \mathrm{A}_{\mathrm{g}}, \mathrm{A}_{\mathrm{b}}$ and $\mathrm{A}_{\mathrm{c}}$ were calculated considering the actual combinations of poppet and seat design, Rabie (2009).

$$
\begin{aligned}
& A_{f}(x)= \begin{cases}0 & x_{a 2} \leq 0 \\
\pi d_{x} x_{a 2} & x_{a 2}>0\end{cases} \\
& A_{g}= \begin{cases}0 & x_{a 2} \geq s_{2} \\
\pi\left(s_{2}-x_{a 2}\right) \sin \beta\left[d_{g}+\left(s_{2}-x_{a 2}\right) \sin \beta \cos \beta\right] & x_{a 2}<s_{2}\end{cases}
\end{aligned}
$$




$$
\begin{aligned}
& \mathrm{A}_{\mathrm{b}}(\mathrm{z})= \begin{cases}0 & \mathrm{x}_{\mathrm{b} 2} \leq 0 \\
\pi \mathrm{d}_{\mathrm{z}} \mathrm{x}_{\mathrm{b} 2} & \mathrm{x}_{\mathrm{b} 2}>0\end{cases} \\
& \mathrm{A}_{\mathrm{c}}= \begin{cases}0 & \mathrm{x}_{\mathrm{b} 2} \geq \mathrm{s}_{2} \\
\pi\left(\mathrm{s}_{2}-\mathrm{x}_{\mathrm{b} 2}\right) \sin \beta\left[\mathrm{d}_{\mathrm{c}}+\left(\mathrm{s}_{2}-\mathrm{x}_{\mathrm{b} 2}\right) \sin \beta \cos \beta\right] & \mathrm{x}_{\mathrm{b} 2}<\mathrm{s}_{2}\end{cases}
\end{aligned}
$$

The following are the continuity equations applied to valve chambers for rigid walls and constant total oil volume and bulk modulus. The valve ports A \& B are closed by the pressure gauges.

$$
\begin{aligned}
& Q_{b}-Q_{c}=\frac{V_{3}}{B} \frac{d}{d t}\left[P_{B}\right] \\
& Q_{f}-Q_{g}=\frac{V_{4}}{B} \frac{d}{d t}\left[P_{A}\right]
\end{aligned}
$$

The motion of the solenoids cores and poppets are described by the following equations, considering the contact and seats reaction forces (see Fig.3)

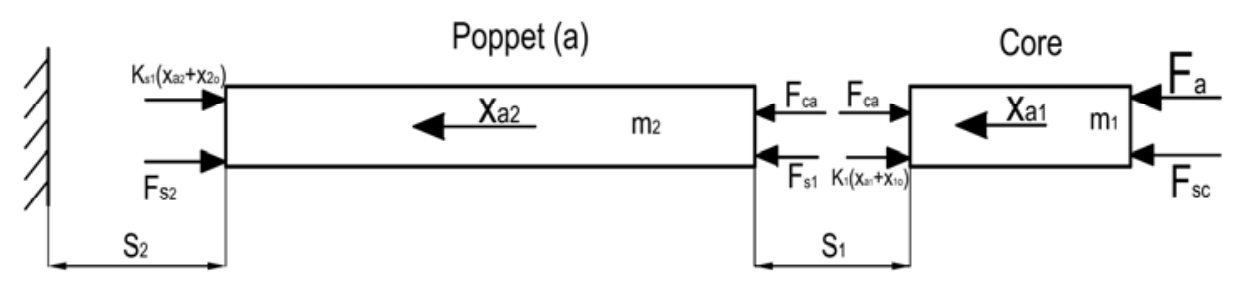

Fig. 3 Free-body diagram of the DCV poppet and solenoid core, section (a)

$$
\begin{aligned}
& \mathrm{F}_{\mathrm{ca}}+\mathrm{F}_{\mathrm{S} 1}-\mathrm{F}_{\mathrm{S} 2}=\mathrm{m}_{2} \ddot{\mathrm{x}}_{\mathrm{a} 2}+\mathrm{f}_{\mathrm{r}} \dot{\mathrm{x}}_{\mathrm{a} 2}+\mathrm{k}_{\mathrm{s} 1}\left(\mathrm{x}_{\mathrm{a} 2}+\mathrm{x}_{2 \mathrm{o}}\right) \\
& \mathrm{F}_{\mathrm{sc}}+\mathrm{F}_{\mathrm{a}}-\mathrm{F}_{\mathrm{ca}}=\mathrm{m}_{1} \ddot{\mathrm{x}}_{\mathrm{a} 1}+\mathrm{f}_{\mathrm{r}} \dot{\mathrm{x}}_{\mathrm{a} 1}+\mathrm{k}_{1}\left(\mathrm{x}_{\mathrm{a} 1}+\mathrm{x}_{1 \mathrm{o}}\right) \\
& \mathrm{F}_{\mathrm{cb}}+\mathrm{F}_{\mathrm{S} 3}-\mathrm{F}_{\mathrm{S} 4}=\mathrm{m}_{2} \ddot{\mathrm{x}}_{\mathrm{b} 2}+\mathrm{f}_{\mathrm{r}} \dot{\mathrm{x}}_{\mathrm{b} 2}+\mathrm{k}_{\mathrm{s} 2}\left(\mathrm{x}_{\mathrm{b} 2}+\mathrm{x}_{2 \mathrm{o}}\right) \\
& \mathrm{F}_{\mathrm{sd}}+\mathrm{F}_{\mathrm{b}}-\mathrm{F}_{\mathrm{cb}}=\mathrm{m}_{1} \ddot{\mathrm{x}}_{\mathrm{b} 1}+\mathrm{f}_{\mathrm{r}} \dot{\mathrm{x}}_{\mathrm{b} 1}+\mathrm{k}_{2}\left(\mathrm{x}_{\mathrm{b} 1}+\mathrm{x}_{1 \mathrm{o}}\right)
\end{aligned}
$$

The seat reaction and contact forces, acting on the poppets and solenoids core are given by the following equations.

$$
\begin{aligned}
\mathrm{F}_{\mathrm{ca}} & = \begin{cases}0 & \mathrm{x}_{\mathrm{a} 2}>\mathrm{x}_{\mathrm{a} 1} \\
\mathrm{k}_{\mathrm{cp}}\left|\mathrm{x}_{\mathrm{a} 2}-\mathrm{x}_{\mathrm{a} 1}\right|-\mathrm{f}_{\mathrm{rcp}}\left(\dot{\mathrm{x}}_{\mathrm{a} 2}-\dot{\mathrm{x}}_{\mathrm{a} 1}\right) & \mathrm{x}_{\mathrm{a} 2} \leq \mathrm{x}_{\mathrm{a} 1}\end{cases} \\
\mathrm{F}_{\mathrm{s} 1} & = \begin{cases}0 & \mathrm{x}_{\mathrm{a} 2}>0 \\
\mathrm{k}_{\mathrm{ca}}\left|\mathrm{x}_{\mathrm{a} 2}-\mathrm{x}_{\mathrm{a} 2 \mathrm{i}}\right|+\mathrm{f}_{\mathrm{rc}} \dot{\mathrm{x}}_{\mathrm{a} 2} & \mathrm{x}_{\mathrm{a} 2} \leq 0\end{cases} \\
\mathrm{F}_{\mathrm{s} 2} & = \begin{cases}0 & \mathrm{x}_{\mathrm{a} 2}<\mathrm{s}_{2} \\
\mathrm{k}_{\mathrm{pa}}\left|\mathrm{x}_{\mathrm{a} 2}-\mathrm{x}_{\mathrm{a} 2 \mathrm{i}}\right|+\mathrm{f}_{\mathrm{rc}} \dot{\mathrm{x}}_{\mathrm{a} 2} & \mathrm{x}_{\mathrm{a} 2} \geq \mathrm{s}_{2}\end{cases} \\
\mathrm{F}_{\mathrm{sc}} & = \begin{cases}0 & \mathrm{x}_{\mathrm{a} 1}>-\mathrm{s}_{1} \\
\mathrm{k}_{\mathrm{c}}\left|\mathrm{x}_{\mathrm{a} 1}-\mathrm{x}_{\mathrm{a} 1 \mathrm{i}}\right|+\mathrm{f}_{\mathrm{rc}} \dot{\mathrm{x}}_{\mathrm{a} 1} & \mathrm{x}_{\mathrm{a} 1} \leq-\mathrm{s}_{1}\end{cases} \\
\mathrm{F}_{\mathrm{cb}} & = \begin{cases}0 & \mathrm{x}_{\mathrm{b} 2}>\mathrm{x}_{\mathrm{b} 1} \\
\mathrm{k}_{\mathrm{cp}}\left|\mathrm{x}_{\mathrm{b} 2}-\mathrm{x}_{\mathrm{b} 1}\right|-\mathrm{f}_{\mathrm{rcp}}\left(\dot{\mathrm{x}}_{\mathrm{b} 2}-\dot{\mathrm{x}}_{\mathrm{b} 1}\right) & \mathrm{x}_{\mathrm{b} 2} \leq \mathrm{x}_{\mathrm{b} 1}\end{cases} \\
\mathrm{F}_{\mathrm{s} 3} & = \begin{cases}0 & \mathrm{x}_{\mathrm{b} 2}>0 \\
\mathrm{k}_{\mathrm{cb}}\left|\mathrm{x}_{\mathrm{b} 2}-\mathrm{x}_{\mathrm{b} 2 \mathrm{i}}\right|+\mathrm{f}_{\mathrm{r}} \dot{\mathrm{x}}_{\mathrm{b} 2} & \mathrm{x}_{\mathrm{b} 2} \leq 0\end{cases} \\
\mathrm{F}_{\mathrm{s} 4} & = \begin{cases}0 & \mathrm{x}_{\mathrm{b} 2}<\mathrm{s}_{2} \\
\mathrm{k}_{\mathrm{pb}}\left|\mathrm{x}_{\mathrm{b} 2}-\mathrm{x}_{\mathrm{b} 2 \mathrm{i}}\right|+\mathrm{f}_{\mathrm{r}} \dot{\mathrm{x}}_{\mathrm{b} 2} & \mathrm{x}_{\mathrm{b} 2} \geq \mathrm{s}_{2}\end{cases}
\end{aligned}
$$




$$
\mathrm{F}_{\mathrm{sd}}=\left\{\begin{array}{lr}
0 & \mathrm{x}_{\mathrm{b} 1}>-\mathrm{s}_{1} \\
\mathrm{k}_{\mathrm{c}}\left|\mathrm{x}_{\mathrm{b} 1}-\mathrm{x}_{\mathrm{b} 1 \mathrm{i}}\right|+\mathrm{f}_{\mathrm{rc}} \dot{\mathrm{x}}_{\mathrm{b} 1} & \mathrm{x}_{\mathrm{b} 1} \leq-\mathrm{s}_{1}
\end{array}\right.
$$

The directional control valve is described by equations 2.1 thru 2.22. These equations were used to develop a Simulink computer simulation program. The transient response of the DCV, calculated using the simulation program is plotted in Fig. 4 . When acted on by the solenoid force, the solenoid core moves (line $0-b$ ), while the poppet is stationary (line $a-b$ ). When the core covers the clearance $\left(s_{1}\right)$ it impacts the poppet (point $b$ ). It decelerates and the poppet accelerates, and they move as one piece after the impact (line b-c). They continue to displace until they reach the end position seat (line c-d). The duration of the valve response, until reaching the end position, is within $22 \mathrm{~ms}$. The transient response of the exit port pressure $\left(\mathrm{P}_{\mathrm{A}}\right)$, calculated for different input pressure levels, with the port closed, is plotted in Fig. 5 . This figure shows that the valve presents an over damped transient response of about $17 \mathrm{~ms}$ settling.

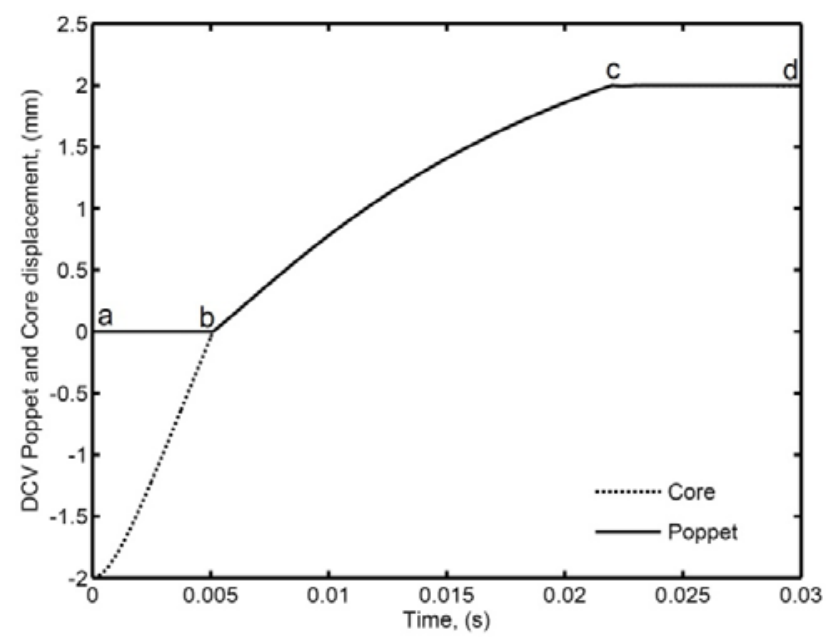

Fig. 4. Transient response of the core and poppet displacements to step solenoid

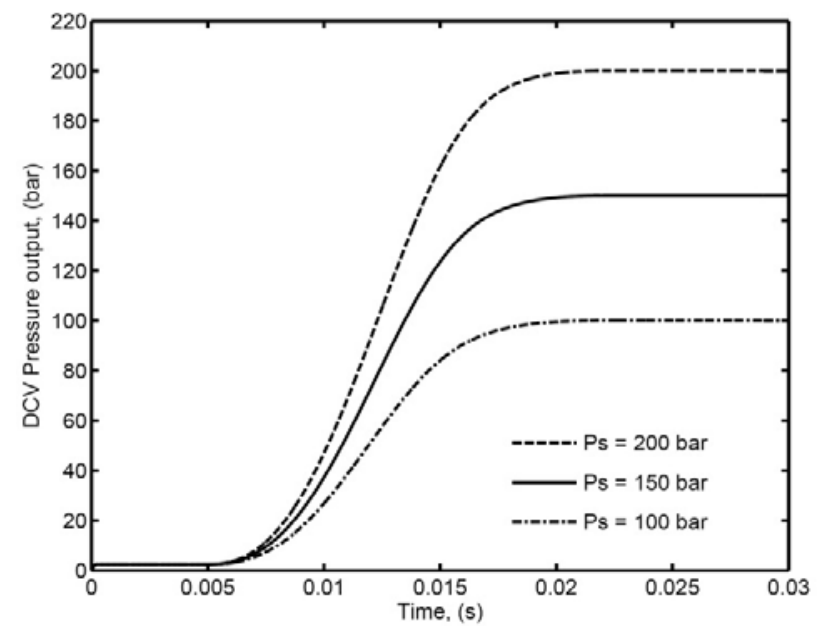

Fig. 5. Transient response of DCV exit pressure to step input of solenoid force (Fa), for different input pressure values. 
Paper: ASAT-13-HC-03

\section{Pressure Reducing Valve}

The pressure reducing valve (See Fig.6-a) consists of: valve body (7), inlet poppet valve (1), drain poppet valve (4), piston (6), spring (5), poppet (3), spring (2) and screw with guide (8). When port (A) is not pressurized, piston (6) is pressed by spring (5) to the extreme left position, and poppet valve (1) is widely open. The spring (2) keeps the right conical end pressed against seat (4), connecting chamber (A) with chamber (D). As the pressure azxt port (A) increases, the pressure in the chamber (D) increases as well. Acting on piston (6), the pressure of the operating fluid shifts the piston, together with the poppet to the right compressing spring (5). The annular slot area between the left cone of poppet (3) and left seat is progressively decreased to become fully closed (See Fig.6-b), and the pressure at port (C) is held constant to the preset reduced value controlled by the initial force of spring (5).

(a)

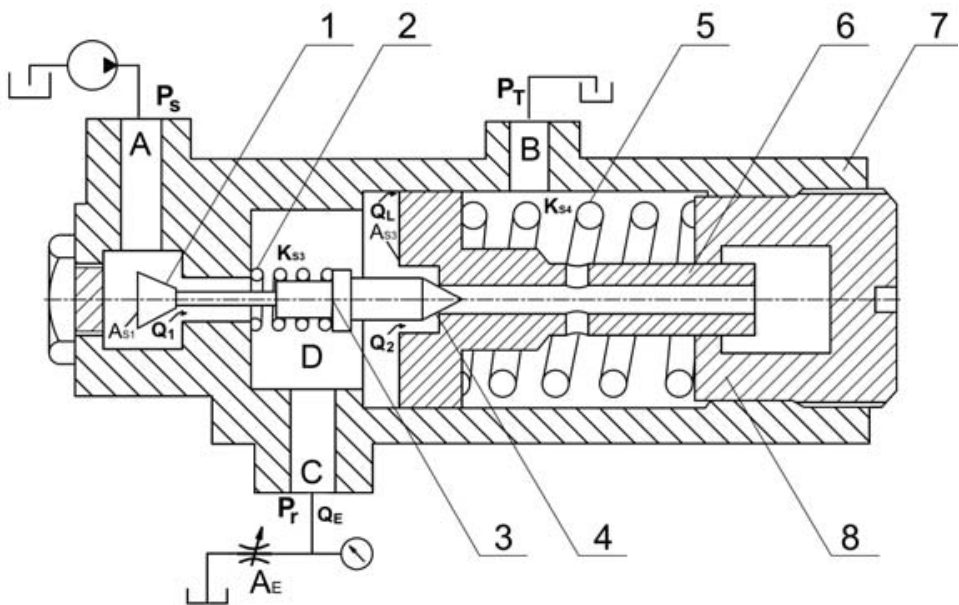

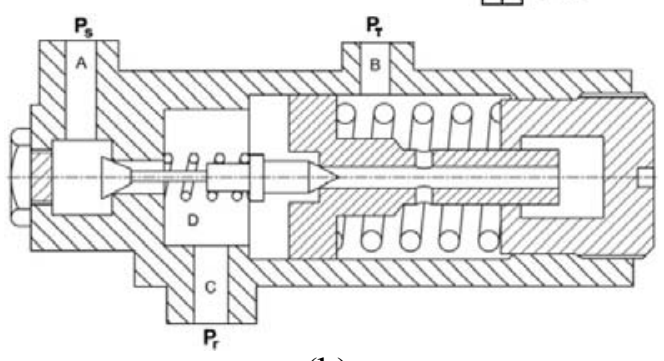

(b)

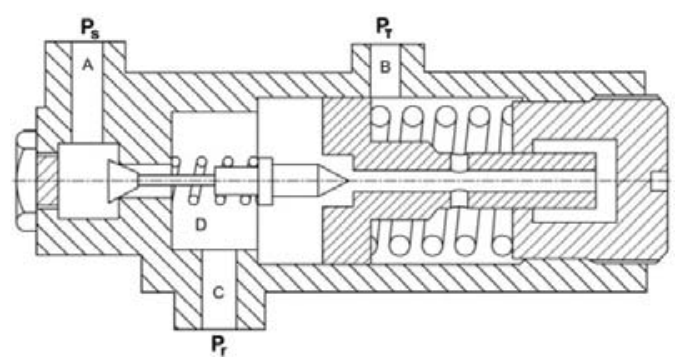

(c)

Fig. 6 Schematic of the pressure reducing valve.

As the downstream pressure of the reducing valve drops, the spring shifts the piston(6), together with poppet (3) to the left to let the operating fluid pass from the high pressure port (A) to the reduced pressure chamber (D) to keep its pressure at the preset value. When the pressure in the reduced pressure line gets higher, the pressure on piston (6) increases forcing piston (6) to move to the right. As poppet (3) stays in position, valve (4) opens connecting chamber (D) to return line (See Fig.6-c). The fluid flow rates through the valve restrictions are given by the following relations.

$$
\begin{array}{r}
\mathrm{Q}_{1}=\mathrm{C}_{\mathrm{d}} \mathrm{A}_{1} \sqrt{2\left(\mathrm{P}_{\mathrm{s}}-\mathrm{P}_{\mathrm{r}}\right) / \rho} \\
\mathrm{Q}_{2}=\mathrm{C}_{\mathrm{d}} \mathrm{A}_{2} \sqrt{2\left(\mathrm{P}_{\mathrm{r}}-\mathrm{P}_{\mathrm{T}}\right) / \rho} \\
\mathrm{Q}_{\mathrm{L}}=\left(\mathrm{P}_{\mathrm{r}}-\mathrm{P}_{\mathrm{T}}\right) / \mathrm{R}_{\mathrm{L}} \\
\mathrm{Q}_{\mathrm{E}}=\mathrm{C}_{\mathrm{d}} \mathrm{A}_{\mathrm{E}} \sqrt{2\left(\mathrm{P}_{\mathrm{r}}-\mathrm{P}_{\mathrm{T}}\right) \rho}
\end{array}
$$




$$
\mathrm{R}_{\mathrm{L}}=12 \mu \mathrm{L} /\left(\pi \mathrm{d}_{5} \mathrm{c}^{3}\right)
$$

The valve throttling area $\left(\mathrm{A}_{1}, \mathrm{~A}_{2}\right.$ and $\left.\mathrm{A}_{\mathrm{E}}\right)$ are given by:

$$
\begin{aligned}
& A_{1}=\left\{\begin{array}{lc}
0 & x_{c 1} \geq x_{n} \\
\pi\left(x_{n}-x_{c 1}\right) \sin \varphi\left[d_{6}-\left(x_{n}-x_{c 1}\right) \sin (\varphi) \cos (\varphi)\right] & x_{c 1}<x_{n}
\end{array}\right. \\
& A_{2}= \begin{cases}0 & x_{c 1} \geq x_{c 2} \\
\pi\left(x_{c 2}-x_{c 1}\right) \sin \tau\left[d_{3}-\left(x_{c 2}-x_{c 1}\right) \sin (\tau) \cos (\tau)\right] & x_{c 1}<x_{c 2}\end{cases} \\
& A_{E}=R
\end{aligned}
$$

The application of continuity equation to chamber (D) yields:

$$
\mathrm{Q}_{1}-\mathrm{Q}_{2}-\mathrm{Q}_{\mathrm{L}}-\mathrm{Q}_{\mathrm{E}}=\frac{\mathrm{V}_{\mathrm{c}}+\mathrm{A}_{\mathrm{s} 3} \mathrm{x}_{\mathrm{c} 2}+\left(\mathrm{A}_{\mathrm{s} 1}-\mathrm{A}_{\mathrm{s} 2}\right) \mathrm{x}_{\mathrm{c} 2}}{\mathrm{~B}} \frac{\mathrm{d}}{\mathrm{dt}} \mathrm{P}_{\mathrm{r}}
$$

The areas $A_{S 1}, A_{S 2}$ and $A_{S 3}$ are given by the following equations.

$$
\begin{aligned}
& \mathrm{A}_{\mathrm{s} 1}=\frac{\pi}{4}\left(\mathrm{~d}_{2}\right)^{2}=\frac{\pi}{4}\left\{\mathrm{~d}_{6}-2\left(\mathrm{x}_{\mathrm{n}}-\mathrm{x}_{\mathrm{c} 1}\right) \sin (\varphi) \cos (\varphi)\right\}^{2} \\
& \mathrm{~A}_{\mathrm{s} 2}=\frac{\pi}{4}\left(\mathrm{~d}_{4}\right)^{2}=\frac{\pi}{4}\left\{\mathrm{~d}_{3}-2\left(\mathrm{x}_{\mathrm{c} 2}-\mathrm{x}_{\mathrm{c} 1}\right) \sin (\tau) \cos (\tau)\right\}^{2} \\
& \mathrm{~A}_{\mathrm{S} 3}=\frac{\pi}{4}\left(\mathrm{~d}_{5}-\mathrm{d}_{3}\right)^{2}
\end{aligned}
$$

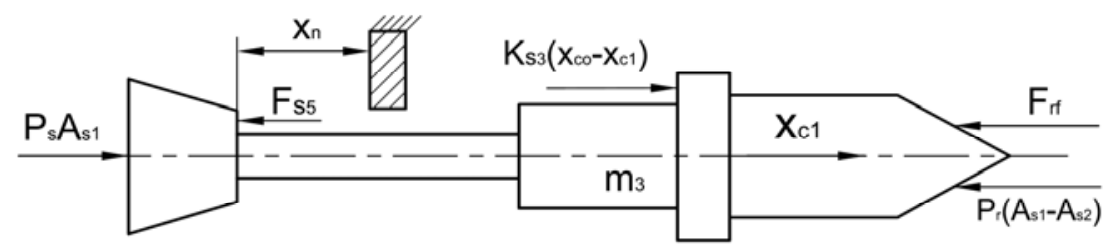

Fig. 7 Free body diagram of poppet.

The following is the equation of motion of the valve poppet (See Fig.7).

$$
\begin{aligned}
\mathrm{P}_{\mathrm{s}} \mathrm{A}_{\mathrm{s} 1}-\mathrm{P}_{\mathrm{r}}\left(\mathrm{A}_{\mathrm{s} 1}-\mathrm{A}_{\mathrm{s} 2}\right)+\mathrm{K}_{\mathrm{s} 3}\left(\mathrm{x}_{\mathrm{co}}-\mathrm{x}_{\mathrm{c} 1}\right)-\mathrm{F}_{\mathrm{s} 5}-\mathrm{F}_{\mathrm{rf}}=\mathrm{m}_{3} \ddot{\mathrm{x}}_{\mathrm{c} 1}+\mathrm{f}_{\mathrm{r}} \dot{\mathrm{x}}_{\mathrm{c} 1} & \mathrm{x}_{\mathrm{c} 2}>\mathrm{x}_{\mathrm{c} 1} \\
\mathrm{~F}_{\mathrm{rf}} & = \begin{cases}0 & \mathrm{x}_{\mathrm{c} 2} \leq \mathrm{x}_{\mathrm{c} 1} \\
\mathrm{~K}_{\mathrm{p}}\left|\left(\mathrm{x}_{\mathrm{c} 2}-\mathrm{x}_{\mathrm{c} 1}\right)\right|-\mathrm{f}_{\mathrm{rp}}\left(\dot{\mathrm{x}}_{\mathrm{c} 2}-\dot{\mathrm{x}}_{\mathrm{c} 1}\right) & \mathrm{x}_{\mathrm{c} 1}<\mathrm{x}_{\mathrm{n}}\end{cases} \\
\mathrm{F}_{\mathrm{s} 5} & = \begin{cases}0 & \mathrm{x}_{\mathrm{c} 1} \geq \mathrm{x}_{\mathrm{n}}\end{cases}
\end{aligned}
$$

The poppet rests on the piston during most of the valve operating period, except when the valve operates as a relief valve (See Fig.8). The motion of piston is described as follows.

$$
\begin{aligned}
& \mathrm{P}_{\mathrm{r}} \mathrm{A}_{\mathrm{s} 3}+\mathrm{F}_{\mathrm{rf}}+\mathrm{F}_{\mathrm{s} 6}-\mathrm{K}_{\mathrm{s} 4}\left(\mathrm{x}_{\mathrm{c} 2}+\mathrm{x}_{\mathrm{c} 2 \mathrm{o}}\right)=\mathrm{m}_{4} \ddot{\mathrm{x}}_{\mathrm{c} 2}+\mathrm{f}_{\mathrm{r}} \dot{\mathrm{x}}_{\mathrm{c} 2} \mathrm{x}_{\mathrm{c} 2}>0 \\
& \mathrm{~F}_{\mathrm{s} 6}= \begin{cases}0 & \mathrm{x}_{\mathrm{c} 2} \leq 0 \\
\mathrm{~K}_{\mathrm{st} 6}\left|\left(\mathrm{x}_{\mathrm{c} 2}\right)\right|-\mathrm{f}_{\mathrm{rst} 6}\left(\dot{\mathrm{x}}_{\mathrm{c} 2}\right) & \end{cases}
\end{aligned}
$$

The pressure reducer is described mathematically by Eqs. 3.1 thru 3.17. These equations were used to develop a Simulink simulation program for the pressure reducer. The transient 
response of the pressure reducer to step increase of input pressure was calculated by the simulation program and plotted in Fig. 9. The exit valve pressure reaches a steady state value of 80 bar, with steady state error within $2 \%$, over the whole practical range of variation of input pressure level.

The transient response of the reduced pressure to step input pressure applied at time $\mathrm{t}=10 \mathrm{~ms}$, followed by step opening of the loading throttle to $1 \mathrm{~mm}^{2}$ at time $\mathrm{t}=30 \mathrm{~ms}$ was calculated. The calculation results are plotted in Fig.10. By the opening of the loading valve (See Fig.6a), the valve exit pressure decreases. Its steady state value is determined by the input and load pressures as the throttling in the fluid throttling in the valve.

The transient response of the piston and poppet was calculated for a step input pressure of 150 bar applied at time $t=10 \mathrm{~ms}$ and step opening of loading orifice applied at $t=30 \mathrm{~ms}$. The calculation results are plotted in Fig.11. This figure shows that both of the two elements move as one part. They present a settling time of within $15 \mathrm{~ms}$.

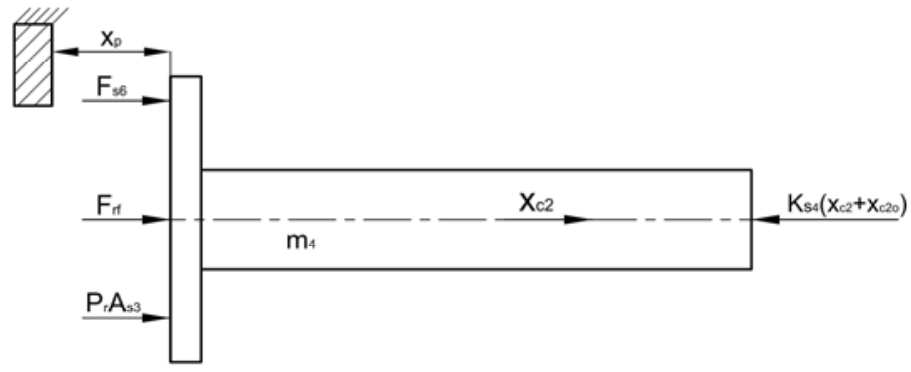

Fig. 8 Free body diagram of piston.

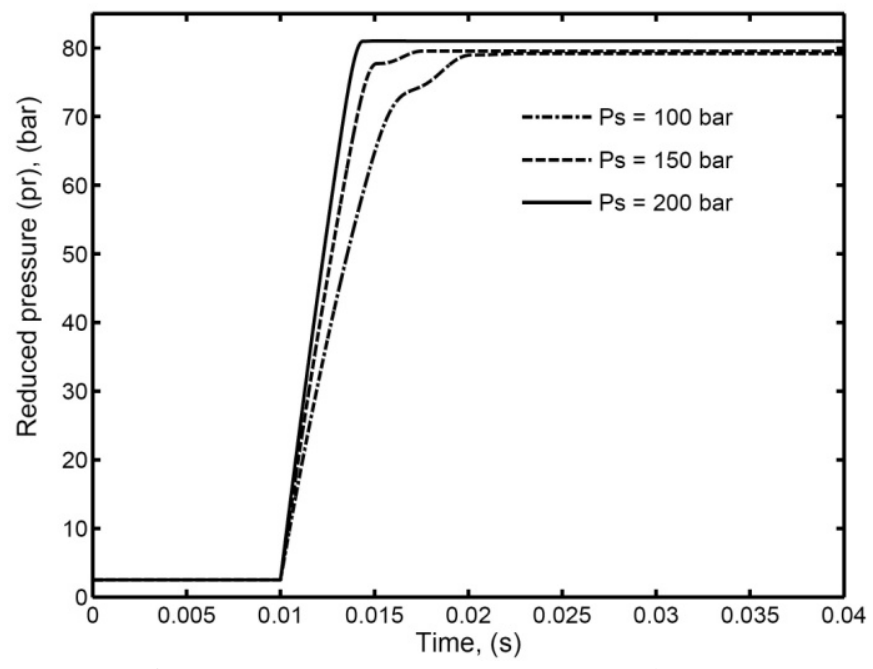

Fig. 9 Transient response of the reduced pressure to step input pressure of different values, for closed loading 


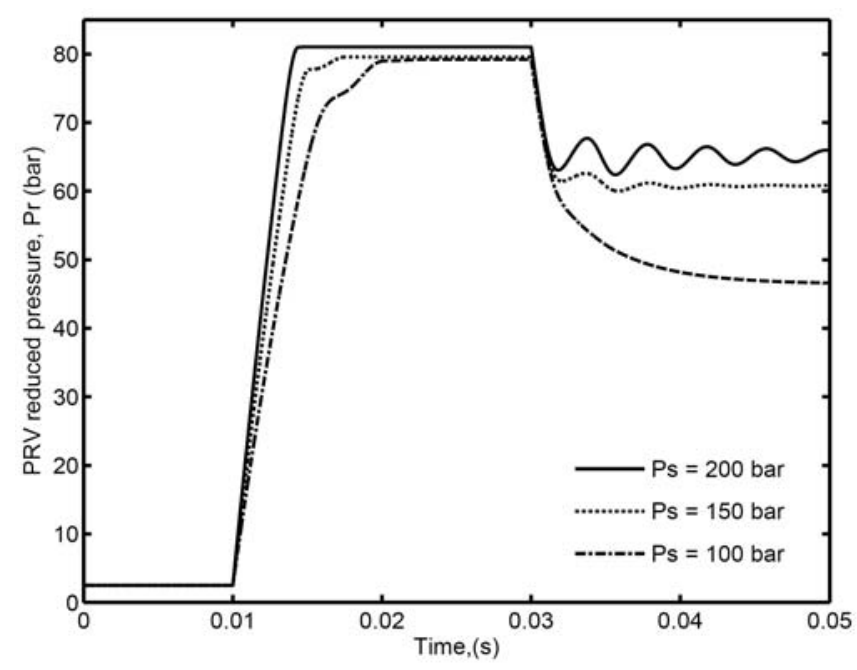

Fig. 10 Transient response of the reduced pressure to step input pressure of different values, and initially closed loading orifice, then step opened at $t=0.03 \mathrm{~s}$

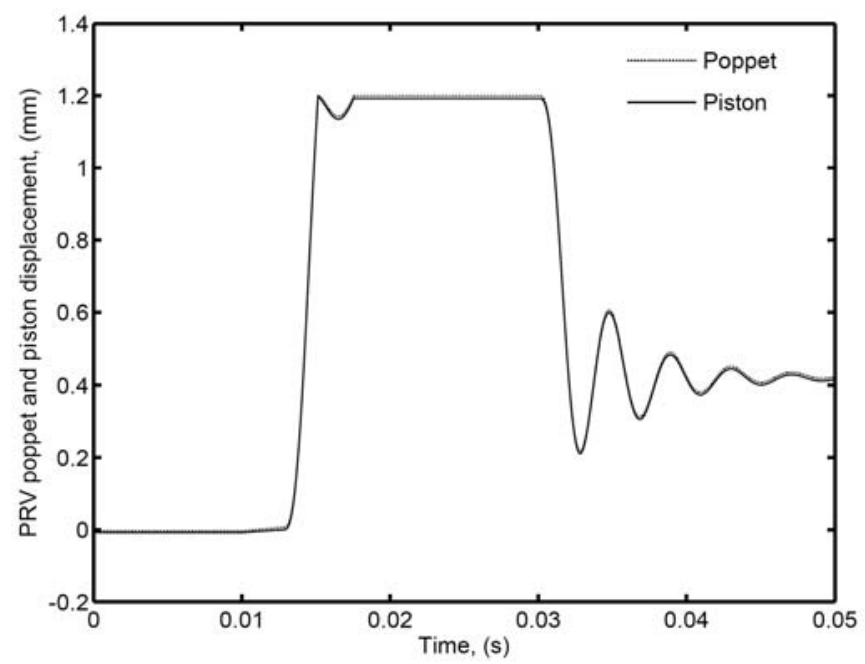

Fig. 11 The poppet and piston responses for step input pressure of 150 bar applied at time $t=10 \mathrm{~ms}$ and step opening of loading orifice applied at $t=30 \mathrm{~ms}$

\section{Check Valve}

the check valve, (See Fig.12), comprises a poppet (1) and a spring (2) and a housing (4 \& 5). The poppet is pushed against its seat by the spring force. The valve is basically designed to allow fluid to flow in one direction, from port (I) to port $(\mathrm{H})$, while the fluid flow in the opposite direction is completely blocked. 


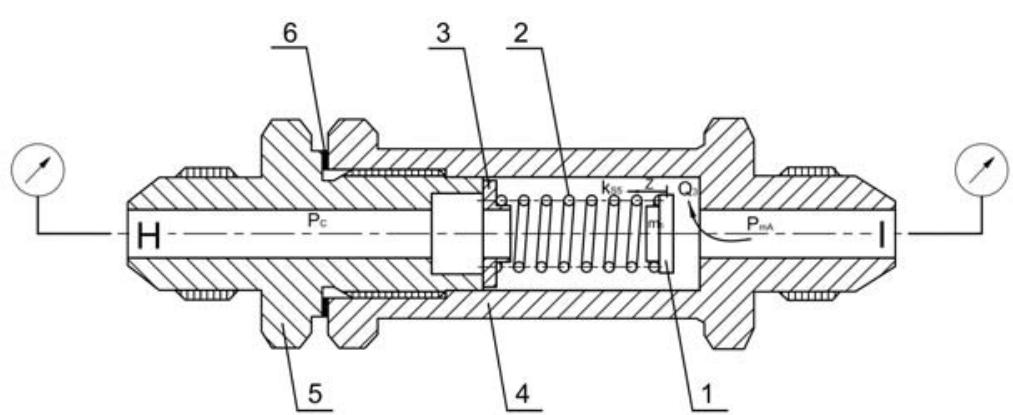

Fig. 12 Schematic diagram of Check Valve.

The valve opens, allowing the fluid flow from port $(\mathrm{I})$ to port $(\mathrm{H})$, when the pressure force $\left[\mathrm{A}_{\mathrm{r}}\right.$ $\left.\left(\mathrm{P}_{\mathrm{mA}}-\mathrm{P}_{\mathrm{C}}\right)\right]$ is greater than the spring force $\left(\mathrm{k} \mathrm{x}_{\mathrm{o}}\right)$. The dynamic behavior of the valve is described by the following equations.

$$
\begin{aligned}
\left(\mathrm{P}_{\mathrm{mA}}-\mathrm{P}_{\mathrm{C}}\right) \mathrm{A}_{\mathrm{r}}-\mathrm{K}_{\mathrm{S} 5}\left(\mathrm{Z}+\mathrm{Z}_{\mathrm{o}}\right)+\mathrm{F}_{\mathrm{S} 7}-\mathrm{F}_{\mathrm{S} 8}=\mathrm{m}_{5} \ddot{\mathrm{Z}}+\mathrm{f}_{\mathrm{r}} \mathrm{Z} \\
\mathrm{F}_{\mathrm{s} 7}= \begin{cases}0 & \mathrm{z}>0 \\
\mathrm{k}_{\mathrm{st} 7}|\mathrm{z}|+\mathrm{f}_{\mathrm{cv}} \mathrm{z} & \mathrm{z} \leq 0\end{cases} \\
\mathrm{F}_{\mathrm{s} 8}= \begin{cases}0 & \mathrm{z}<4 \\
\mathrm{k}_{\mathrm{st} 8}|\mathrm{z}|+\mathrm{f}_{\mathrm{cv}} \mathrm{z} & \mathrm{z} \geq 4\end{cases} \\
\mathrm{A}_{\mathrm{r}}=\frac{\pi}{4} \mathrm{~d}_{\mathrm{L}}^{2} \\
\mathrm{Q}_{3}=\mathrm{C}_{\mathrm{d}} \mathrm{A}_{\mathrm{t}}(\mathrm{z}) \sqrt{2\left(\mathrm{P}_{\mathrm{mA}}-\mathrm{P}_{\mathrm{C}}\right) / \rho} \\
\mathrm{A}_{\mathrm{t}}(\mathrm{z})= \begin{cases}0 & \mathrm{z} \leq 0 \\
\pi \mathrm{d}_{\mathrm{t}} \mathrm{z} & \mathrm{z}>0\end{cases}
\end{aligned}
$$

\section{Hydraulic Motor}

The studied hydraulic motor is shown by Fig.13. It consists of front casing (1), rear casing (2), port plate (3), cylinder block (4), piston head (5), piston rod assembly (6), bearing set (7), leakage port (8) and output shaft (9).

The input high pressure flow rate $\left(\mathrm{Q}_{\text {in }}\right)$ is supplied through the port plate (3), to cylinder block (4) and pistons chambers (5). After rotation of motor axle by $180^{\circ}$, the pistons reverse their direction of motion, displacing the oil to the return line, through the port plate. The total returned flow rate is $\left(\mathrm{Q}_{\mathrm{dr}}\right)$. The pistons of chambers connected to the high pressure line are acted on by the pressure force. This force is resolved at the spherical end of the connecting rods into axial and tangential components. The axial component is supported by the bearing while the tangential component drives the motor shaft against the loading torque. Therefore, the supply pressure depends on the loading torque and the motor speed depends on the supply flow rate.

The fluid flow to and from the cylinder chambers is controlled by inlet and outlet restrictions. The areas of these restrictions are determined by the shape of the cylinder port diameter and the geometry of the two kidney shaped holes on the port plate as well as the rotational angle of the cylinder block (See Fig.13-b). Figure 14 shows the calculated drain and intake 
throttling areas considering the geometry of the studied motor. The flow rates inlet and drained from the motor can be calculated by the following equations.

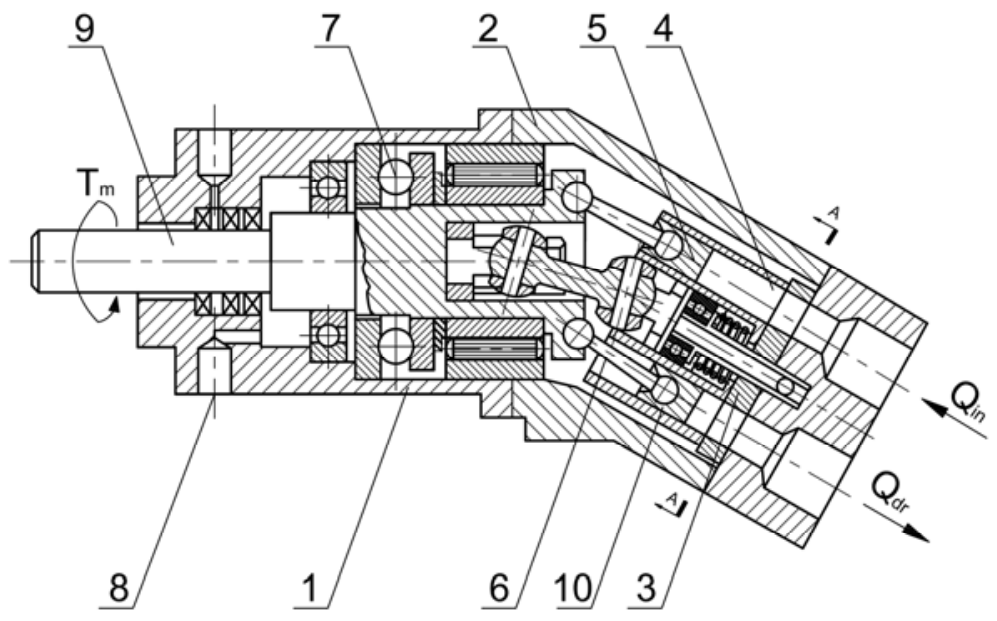

(a)

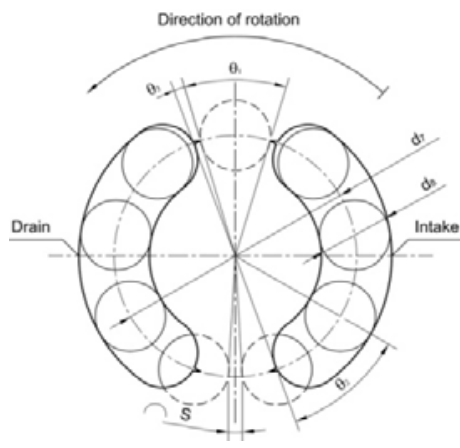

(b)

Fig.13 Schematic diagram of Hydraulic Motor and its port plate

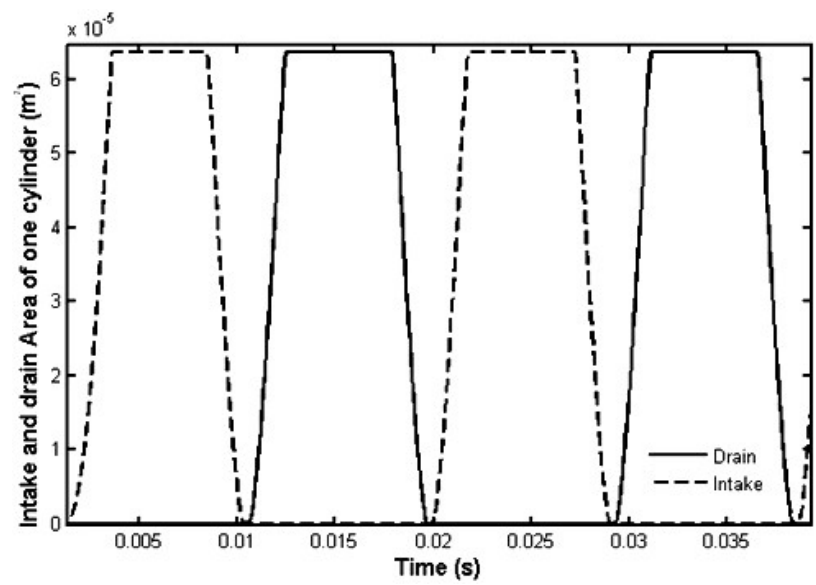

Fig. 14. Variation of the intake and drain throttle areas of the individual chambers with the motor rotational angle

$$
\begin{array}{r}
\mathrm{Q}_{\mathrm{ini}}=\mathrm{C}_{\mathrm{d}} \mathrm{A}_{\mathrm{ini}} \sqrt{2\left(\mathrm{P}_{\mathrm{s}}-\mathrm{P}_{\mathrm{ci}}\right) / \rho} \\
\mathrm{Q}_{\mathrm{dri}}=\mathrm{C}_{\mathrm{d}} \mathrm{A}_{\mathrm{dri}} \sqrt{2\left(\mathrm{P}_{\mathrm{ci}}-\mathrm{P}_{\mathrm{T}}\right) / \rho} \\
\mathrm{Q}_{\mathrm{in}}=\sum_{1}^{\mathrm{i}} \mathrm{Q}_{\mathrm{ini}} \\
\mathrm{Q}_{\mathrm{dr}}=\sum_{1}^{i} \mathrm{Q}_{\mathrm{dri}}
\end{array}
$$


The following is the continuity equation applied to the individual motor cylindrical chambers, taking into consideration the internal leakage and the variation of the chamber volume.

$$
\begin{aligned}
Q_{\text {ini }}-Q_{d r i}-\frac{d x_{i}}{d t} A_{S}-\frac{P_{c i}}{R_{i}}=\frac{V_{c i}+x_{i} A_{S}}{B} \frac{d P_{c i}}{d t} \\
V_{c i}=A_{S} L_{C} \\
A_{S}=\frac{\pi}{4} d_{8}^{2}
\end{aligned}
$$

The piston displacement changes with the motor rotational angle and the cylinder block inclination angle as given by the following equation.

$$
\mathrm{x}_{\mathrm{i}}=\frac{\mathrm{d}_{7}\left(1-\cos \theta_{\mathrm{mi}}\right)}{2 \sin \alpha}
$$

The piston speed can be simply obtained by differentiating Eq. 5.8.

$$
\frac{\mathrm{dx}_{\mathrm{i}}}{\mathrm{dt}}=\frac{\mathrm{d}_{7}}{2 \sin \alpha} \frac{\mathrm{d} \theta_{\mathrm{mi}}}{\mathrm{dt}} \sin \theta_{\mathrm{mi}}
$$

The torque $\mathrm{T}_{\mathrm{mi}}$, which acts on the motor shaft, due to the pressure force acting on the piston is:

$$
\begin{gathered}
\mathrm{T}_{\mathrm{mi}}=\frac{\mathrm{d}_{7}}{2} \mathrm{P}_{\mathrm{ci}} \mathrm{A}_{\mathrm{S}} \sin \alpha \sin \theta_{\mathrm{mi}} \\
\mathrm{T}_{\mathrm{m}}=\sum_{1}^{\mathrm{i}} \mathrm{T}_{\mathrm{mi}}
\end{gathered}
$$

The rotation of the motor shaft, cylinder block and the attached parts is governed by the following equation.

$$
\mathrm{T}_{\mathrm{m}}=\mathrm{J} \ddot{\theta}_{\mathrm{mi}}+\mathrm{f} \dot{\theta}_{\mathrm{mi}}+\mathrm{T}_{\mathrm{L}}
$$

\section{Transmission lines connecting elements}

The inertia and pressure losses in the transmission lines are neglected in this study, compared with the inertia of rotating parts and the motor frictional load. Only the oil compressibility is considered, for computational reasons. The following are the results of application of continuity equation to these lines.

Line connecting port A of DCV with the PRV inlet.

$$
\mathrm{Q}_{\mathrm{A}}-\mathrm{Q}_{\mathrm{rd}}+\mathrm{Q}_{\mathrm{cv}}=\frac{\mathrm{V}_{12}}{\mathrm{~B}} \frac{\mathrm{d}}{\mathrm{dt}}\left[\mathrm{P}_{\mathrm{A}}\right]
$$


Line connecting the PRV outlet port and motor inlet port.

$$
\begin{gathered}
\mathrm{Q}_{\mathrm{r}}-\mathrm{Q}_{\mathrm{m} 1}-\mathrm{Q}_{\mathrm{cv}}=\frac{\mathrm{V}_{23}}{\mathrm{~B}} \frac{\mathrm{d}}{\mathrm{dt}}\left[\mathrm{P}_{\mathrm{r}}\right] \\
\mathrm{Q}_{\mathrm{r}}=\mathrm{Q}_{\mathrm{rd}}-\mathrm{Q}_{2}-\mathrm{Q}_{\mathrm{L}}
\end{gathered}
$$

Line connecting outlet port of motor and port B of DCV.

$$
\begin{aligned}
\mathrm{Q}_{\mathrm{m} 2}+\mathrm{Q}_{\mathrm{B}} & =\frac{\mathrm{V}_{31}}{\mathrm{~B}} \frac{\mathrm{d}}{\mathrm{dt}}\left[\mathrm{P}_{\mathrm{B}}\right] \\
\mathrm{Q}_{\mathrm{B}} & =\mathrm{Q}_{\mathrm{b}}-\mathrm{Q}_{\mathrm{c}}
\end{aligned}
$$

\section{Simulation and Analysis of the Studied System}

Figure 16 shows a schematic of the hydraulic motor and the control valves. This system is mathematically by Eqs. 2.1 thru 6.5. A computer simulation program was developed, on the basis of these equations, using the Simulink. The developed simulation program was used to calculate the transient response of the system.

The transient response of the motor speed to the step increase in the solenoids forces was calculated. The transient response of the solenoid is actually negligible compared with that of the valve since the solenoids cores dynamics are treated separately, by Eqs. 2.12 and 2.14. The solenoids forces were suddenly increases at time $\mathrm{t}=10 \mathrm{~ms}$. The transient responses to sudden actuation of solenoids (a) and (b), (See Fig.2.2), was calculated. The calculation results are plotted in Figs. 16 and 17 respectively. By energizing solenoid (a), the pressurized fluid is fed to the motor through the pressure reducer (See Fig.18). The maximum pressure difference applied to the motor is within 50 bar. In this case study, the motor load is mainly frictional load, proportional to the motor speed. The motor showed a transient response with about $30 \mathrm{~ms}$ settling time and $1300 \mathrm{rpm}$ steady state speed (See Fig.16). When actuating solenoid (b), the pressurized fluid flows directly from the DCV to the motor. The motor exit fluid returns through the check valve, by-passing the pressure reducer. In this case, the maximum pressure difference across the motor is within 120 bar. The motor presents a transient response of about $50 \mathrm{~ms}$ settling time and steady state reverse speed of about 2500 rpm (See Fig.16).

\section{Experimental Work}

A limited experimental work was conducted, aiming to validate the theoretical investigations. The transient response of the motor input pressure was measured while energizing solenoid (a), Fig.1. The pressurized fluid flows to the motor through the pressure reducer, pre-set at 30 bar. The experimental results are plotted in Fig. 18. This figure carries also the simulation results, for the same operating conditions. The study of this figure shows acceptable agreement between the simulation and experimental results. 


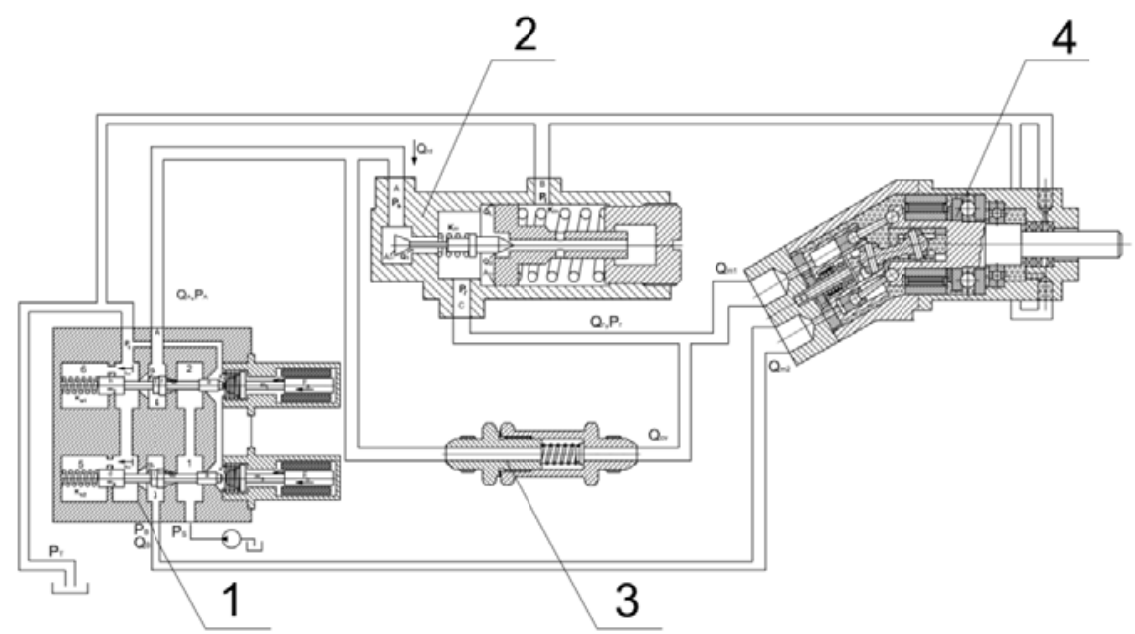

Fig. 15 Schematic of the hydraulic motor and control system

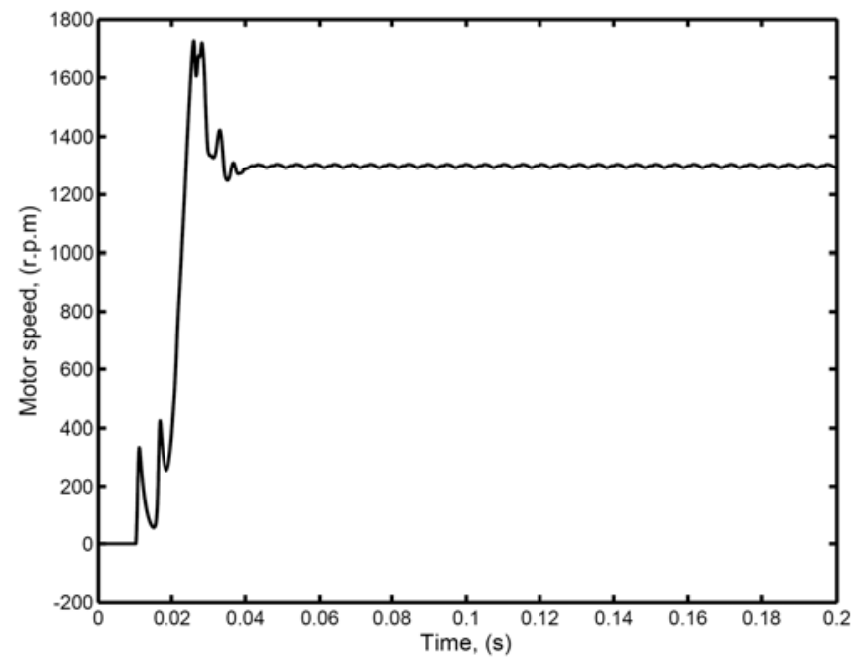

Fig.16 Transient response of the motor speed to step increase of force of solenoid (a) to $25 \mathrm{~N}$, at time $\mathrm{t}=10 \mathrm{~ms}$ 


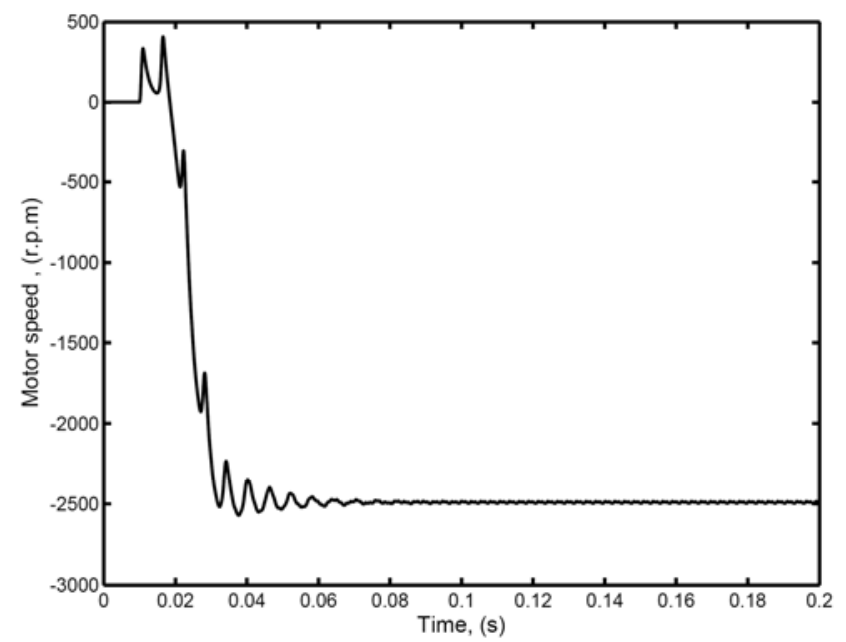

Fig.17 Transient response of the motor speed to step increase of force of solenoid (b) to $25 \mathrm{~N}$, at time $\mathrm{t}=10 \mathrm{~ms}$

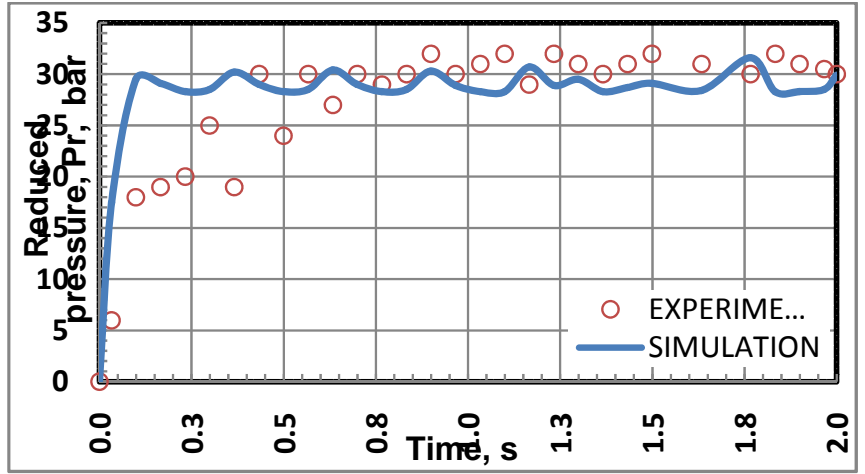

Fig.18 Experimental and simulation results of the motor transient response

\section{Conclusion}

This paper deals with the dynamic behavior of a hydraulic motor, controlled by a system incorporating: a 4/3 poppet type directional control valve, a pressure reducer and a constant pressure hydraulic generator. The individual components and the integrated system were modeled mathematically and simulated by using the Simulink program. The transient response of the individual elements and the system, calculated using the simulation program are presented and analyzed.

The simulation results showed that the transient response of the displacement of the directional control valve poppets is over-damped with about $17 \mathrm{~ms}$ settling time. This response showed the effect of impact forces between the solenoid core and valve poppets. After the impact, they move as one body. 
The transient response of the reduced pressure to step input pressure was calculated. For closed exit port, the valve produced constant reduced pressure, with a steady state error within $2 \%$.

The motor load is mainly frictional load, proportional to the motor speed. In one direction of motor motion, the pressurized fluid is fed to the motor through the pressure reducer. The maximum pressure difference applied to the motor is within 50 bar. The motor showed a transient response with about $30 \mathrm{~ms}$ settling time and $1300 \mathrm{rpm}$ steady state speed. Moreover, in the opposite direction of motor, the pressurized fluid flows directly from the DCV to the motor. The motor exit fluid returns through the check valve, by-passing the pressure reducer. In this case, the maximum pressure difference across the motor is within 120 bar. The motor presents a transient response of about $50 \mathrm{~ms}$ settling time and steady state reverse speed of about $2500 \mathrm{rpm}$.

\section{References}

[1] M. Galal RABIE, Fluid Power Engineering, McGraw-Hill, NY, 2009

[2] P. Smith, Valve Selection Handbook, fifth edition, Burlington, USA, 2004

[3] Matlab Reference Guide - The Math Works Inc, 1997

[4] Mannesmann Rexroth GmbH, Basic Principles and Components of Fluid Technology, volume 1, 1999. 